\title{
Glutathione Peroxidase 3
}

National Cancer Institute

\section{Source}

National Cancer Institute. Glutathione Peroxidase 3. NCI Thesaurus. Code C127004.

Glutathione peroxidase 3 (226 aa, $\sim 26 \mathrm{kDa}$ ) is encoded by the human GPX3 gene. This protein is involved in hydrogen peroxide and lipid peroxide detoxification. 